JAMALI - Jurnal Abdimas Madani dan Lestari

Vol. 01, Issue. 01, Maret 2019, Hal 41-46

(e-ISSN: - ; p-ISSN: - )

https://journal.uii.ac.id/JAMALI

\title{
Edukasi Undang-Undang Nomor 8 Tahun 2016 Tentang Penyandang Disabilitas di Kecamatan Sewon Kabupaten Bantul
}

\author{
Suparman Marzuki, Despan Heryansyah \\ Fakultas Hukum Universitas Islam Indonesia \\ Email: dr.marzuki@uii.ac.id
}

\begin{abstract}
ABSTRAK
Buruknya pelayan publik terhadap penyandang disabilitas ini disebabkan oleh banyak hal, mulai dari latar belakang pendidikan aparatur pemerintahan desa, hingga ke budaya yang selama ini hidup dan berkembang dalam masyarakat bahwa penyandang disabilitas tidak mungkin disamakan dengan orang normal lainnya. Namun demikian, usaha untuk menciptakan pelayanan publik yang setara dan ramah terhadap penyandang disabilitas harus terus dilakukan, hal ini tidak saja dalam rangka melindungi hak asasi manusia setiap warga negara namun juga dalam menjalankan amanat undang-undang dasar.

Menghadapi kondisi itu, Pemerintah Indonesia kemudian mengeluarkan Undang-Undang Nomor 8 Tahun 2016 tentang Penyandang Disabilitas. Undang-undang ini merupakan dasar sekaligus acuan bagi pemerintah dalam memberikan pelayanan terhadap penyandang disabilitas dengan konsep dasar penghormatan terhadap martabat kemanusiaan. Dasar pelayanan terhadap penyandang disabilitas setidaknya berkaitan dengan dua hal yang fokus utamanya adalah pada penghilangan hambatan. Pertama, ketersediaan fasilitas dan keasesibilitasan sarana yang ada agar dapat dijangkau oleh para penyandang disabilitas. Kedua, paradigma pemerintah atau aparatur pemerintah terhadap penyandang disabilitas dalam memberikan pelayanan publik.

Kecamatan Sewon dijadikan sebagai objek pengabdian karena mempertimbangkan kuantitas penyandag disabilitas yang cukup banyak. Memang sampai dengan saat ini, tidak ada jumlah yang pasti mengenai jumlah penyandang disabilitas di kecamatan Sewon, karena memang pemerintah sendiri tidak melakukan database. Harus diakui, ini merupakan salah satu kelemahan yang selama ini terjadi, jangankan tanggap dan respon terhadap sejumlah persoalan yang mereka hadapi, bahkan pendataan mengenai jumlah saja pemerintah setempat tidak memilikinya.
\end{abstract}

Kata Kunci: Penyandang Disabilitas, Pelayanan Publik, Undang-Undang

\section{PEDAHULUAN}

Menjadi difabel ditengah masyarakat yang menganut paham "normalisme", paham pemuja kenormalan, dimana semua sarana umum yang ada didesain khusus untuk orang normal tanpa adanya fasilitas bagi difabel adalah sangat sulit. Dipandang kasihan atau tidak dianggap dalam bermasyarakat adalah sesuatu yang acap kali kita lihat dilingkungan difabel. Bahkan pusat rehabilitasi sekalipun diciptakan menjadikan mereka berbeda dengan orang lain. Terlebih dengan sebutan rehabilitasi difabel disetarakan dengan para pecandu narkotika dan obat obatan terlarang seolah mengalami kecacatan adalah sebuah penyakit yang harus segera diobati. Akan tetapi benarkah menjadi difabel adalah setara dengan digerogoti penyakit? Seseorang yang memang diciptakan dengan satu "perbedaan" oleh Sang Pencipta mungkin tidaklah membutuhkan rehabilitasi melainkan lebih membutuhkan persamaan derajat dan pengakuan dari lingkungannya.

Kenyataan di lapangan menunjukkan kondisi sebaliknya, minimnya sarana pelayanan sosial dan kesehatan serta pelayanan lainnya yang dibutuhkan oleh para difabel, termasuk aksesibilitas 
terhadap pelayanan umum yang dapat mempermudah kehidupan difabel dimana sebagian besar hambatan aksesibilitas tersebut berupa hambatan arsitektural dan budaya, membuat penyandang difabel kehilangan haknya dalam mendapatkan pelayanan yang baik. Dalam hal aksesibilitas, ketersediaan sarana dan prasarana ramah difabel saat ini masih sangat terbatas di Indonesia pada umumnya dan Yogyakarta khususnya. Apalagi jika kita coba melihat lebih jauh pada pemerintahan terendah yaitu pemerintahan desa, maka aksesibulitas terhadap penyandang disabilitas jauh lebih memprihatinkan.

Buruknya pelayan publik terhadap penyandang disabilitas ini disebabkan oleh banyak hal, mulai dari latar belakang pendidikan aparatur pemerintahan desa, hingga ke budaya yang selama ini hidup dan berkembang dalam masyarakat bahwa penyandang disabilitas tidak mungkin disamakan dengan orang normal lainnya. Namun demikian, usaha untuk menciptakan pelayanan publik yang setara dan ramah terhadap penyandang disabilitas harus terus dilakukan, hal ini tidak saja dalam rangka melindungi hak asasi manusia setiap warga negara namun juga dalam menjalankan amanat undang-undang dasar.

Menghadapi kondisi itu, Pemerintah Indonesia kemudian mengeluarkan Undang-Undang Nomor 8 Tahun 2016 tentang Penyandang Disabilitas. Undang-undang ini merupakan dasar sekaligus acuan bagi pemerintah dalam memberikan pelayanan terhadap penyandang disabilitas dengan konsep dasar penghormatan terhadap martabat kemanusiaan. Dasar pelayanan terhadap penyandang disabilitas setidaknya berkaitan dengan dua hal yang fokus utamanya adalah pada penghilangan hambatan. Pertama, ketersediaan fasilitas dan keasesibilitasan sarana yang ada agar dapat dijangkau oleh para penyandang disabilitas. Kedua, paradigma pemerintah atau aparatur pemerintah terhadap penyandang disabilitas dalam memberikan pelayanan publik.A

\section{PERMASALAHAN MITRA}

Adapun permasalahan yang ditemui di Kecamatan Sewon dalam melakukan pelayanan publik adalah sebagai berikut:

1. Terbatasnya sumber daya manusia khususnya sarjana hukum, sehingga setiap peraturan perundang-undangan baru disahkan tidak dapat direspon dengan cepat;

2. Kurangnya perspektif dalam memberikan pelayanan publik kepada para penyandang disabilitas;

3. Paradigma yang masih terbangun memposisikan penyandang disabilitas sebagai orang cacat yang menyulitkan.

\section{METODE KEGIATAN}

Untuk mengatasi berbagai masalah di atas, maka tawaran kegiatan yang diajukan dalam pengabdian ini adalah sebagai berikut:

1. Kegiatan dilakukan dengan model seminar, di mana akan ada tiga pembicara yang akan menyampaikan materi dari berbagai aspek yang berbeda. Salah satu dari pemateri adalah penyandang disabilitas untuk memberikan gambaran berbagai kesulitan yang mereka hadapi dalam menerima pelayanan publik;

2. Kegiatan akan dilanjutkan dengan tanya jawab, di mana masing-masing peserta diberikan waktu yang luas untuk melakukan diskusi dengan para pembicara.

\section{PELAKSANAAN KEGIATAN}

Dalam Convention on the Rights of Persons With Disabilities (CRPD) di mana pemerintah Indonesia telah meratifikasinya ditegaskan kewajiban-kewajiban umum, diantaranya adalah bahwa Negara-Negara Pihak bertanggungjawab menjamin dan meningkatkan realisasi yang utuh dari semua hak asasi manusia dan kebebasan fundamental penyandang disabilitas tanpa diskriminasi. 
Dalam hal ini, pemerintah Indonesia termasuk di dalamnya pemangku kebijakan di lembaga pemasyarakatan wajib memenuhi hak-hak penyandang disabilitas yang rumusan hak-haknya telah disebutkan dalam konvensi.

Konvensi ini juga menegaskan bahwa Negara-Negara Pihak, termasuk pemerintah Indonesia wajib mencegah semua diskriminasi atas dasar disabilitas serta menjamin perlindungan hukum yang sama dan efektif bagi penyandang disabilitas tanpa diskriminasi. Karena itu, pemerintah Indonesia wajib mengambil langkah-langkah yang layak untuk menjamin penyesuaianpenyesuaian sesuai hak-hak penyandang disabilitas.

Di antara langkah-langkah yang wajib dilakukan pemerintah adalah memastikan bahwa penyandang disabilitas dapat hidup mandiri dan berpartisipasi secara penuh. Karena itu, Konvensi ini menegaskan bahwa pemerintah wajib mengambil langkah yang tepat untuk menjamin akses bagi penyandang disabilitas, atas dasar kesamaan dengan warga lainnya, terhadap lingkungan fisik, transprortasi, informasi, komunikasi, termasuk sistem teknologi informasi dan komunikasi, serta akses terhadap fasilitas dan jasa pelayanan. Pemerintah dalam hal ini wajib mengambil langkahlangkah mulai dari identifikasi hingga upaya nyata untuk meminimalkan hambatan-hambatan yang dialami oleh Penyandang Disabilitas.

Norma hukum yang juga mengatur secara spesifik terkait hak-hak penyandang disabilitas adalah Undang-Undang No. 8 Tahun 2016. Dalam Undang-Undang ditegaskan bahwa penyandang disabilitas memiliki kesamaaan kesempatan, ${ }^{1}$ bebas dari diskriminasi berdasar disabilitas, ${ }^{2}$ berhak atas penghormatan, ${ }^{3}$ berhak atas perlindungan, ${ }^{4}$ berhak atas pemenuhan, ${ }^{5}$ berhak atas pemberdayaan, ${ }^{6}$ berhak atas aksesibilitas, ${ }^{7}$ berhak atas akomodasai yang layak, ${ }^{8}$ berhak atas penyediaan alat bantu, ${ }^{9}$ berhak atas alat bantu kesehatan, ${ }^{10}$ berhak atas konsesi, ${ }^{11}$ berhak atas pelayanan publik, ${ }^{12}$ dan berhak atas penyediaan Unit Disabilitas di institusi atau lembaga yang berfungsi sebagai penyedia layanan dan fasilitas untuk penyandang disabilitas.

Ada 5 (lima) hambatan disabilitas yang akan diidentifikasi dalam pengabdian ini, yaitu: Pertama, hambatan fisik dan mobilitas. Identifikasi hambatan ini terkait dengan ketersediaan sarana prasarana yang akses bagi narapidana dan warga binaan penyandang disabilitas. Diantaranya

${ }^{1}$ Kesamaan kesempatan adalah keadaan yang memberikan peluang dan atau menyediakan akses kepada penyandang disabilitas untuk menyalurkan potensi dalam segala aspek penyelenggaraan negara dan masyarakat

${ }^{2}$ Diskriminasi adalah setiap pembedaan, pengecualian, pembatasan, pelecehan atau pengucilan atas dasar disabilitas yang bermaksud atau berdampak pada pembatasan atau peniadaan pengakuan penikmatan, atau pelaksanaan hak-hak penyandang disabilitas

${ }^{3}$ Penghormatan adalah sikap menghargai atau menerima keberadaan penyandang disabilitas dengan segala hak yang melekat tanpa berkurang

${ }^{4}$ Pelindungan adalah upaya yang dilakukan secara sadar untuk melindungi, mengayomi, dan memperkuat hak Penyandang Disabilitas

5 Pemenuhan adalah upaya yang dilakukan untuk memenuhi, melaksanakan, dan mewujudkan hak Penyandang Disabilitas.

6 Pemberdayaan adalah upaya untuk menguatkan keberadaan Penyandang Disabilitas dalam bentuk penumbuhan iklim dan pengembangan potensi sehingga mampu tumbuh dan berkembang menjadi individu atau kelompok Penyandang Disabilitas yang tangguh dan mandiri.

7 Aksesibilitas adalah kemudahan yang disediakan untuk Penyandang Disabilitas guna mewujudkan Kesamaan Kesempatan

${ }^{8}$ Akomodasi yang Layak adalah modifikasi dan penyesuaian yang tepat dan diperlukan untuk menjamin penikmatan atau pelaksanaan semua hak asasi manusia dan kebebasan fundamental untuk Penyandang Disabilitas berdasarkan kesetaraan.

${ }^{9}$ Alat Bantu adalah benda yang berfungsi membantu kemandirian Penyandang Disabilitas dalam melakukan kegiatan sehari-hari.

${ }^{10}$ Alat Bantu Kesehatan adalah benda yang berfungsi mengoptimalkan fungsi anggota tubuh Penyandang Disabilitas berdasarkan rekomendasi dari tenaga medis.

11 Konsesi adalah segala bentuk potongan biaya yang diberikan oleh Pemerintah, Pemerintah Daerah, dan/atau setiap orang kepada Penyandang Disabilitas berdasarkan kebijakan Pemerintah dan Pemerintah Daerah.

12 Pelayanan Publik adalah kegiatan atau rangkaian kegiatan dalam rangka pemenuhan kebutuhan pelayanan sesuai dengan ketentuan peraturan perundang-undangan bagi setiap warga negara dan penduduk atas barang, jasa, dan/atau pelayanan administratif yang disediakan oleh penyelenggara pelayanan publik 
adalah terkait ketersediaan fasilitas gedung yang aksesibel, yakni tersedianya ramp yang standar, lebar pintu, lift untuk bangunan yang bertingkat, guiding block, toilet aksesibel, pencahayaan, dan beberapa sarana prasarana lainnya. Kedua, hambatan perilaku. Identifikasi hambatan ini terkait dengan respon petugas layanan di lembaga pemasyarakatan ketika berinteraksi dengan narapidana dan warga binaan penyandang disabilitas. Ketiga, hambatan hukum dan prosedur. Identifikasi ini terkait dengan ketersediaan aturan, kebijakan dan atau prosedur yang secara langsung mengatur tentang struktur, tugas dan aturan-aturan yang menjamin pemenuhan hak-hak narapidana dan warga binaan penyandang disabilitas. Keempat, hambatan teknologi, informasi dan komunikasi. Identifikasi hambatan ini terkait ketersediaan meja informasi, penerjemah bahasa isyarat, papan petunjuk (signage), dan informasi yang disampaikan dalam ragam bentuk seperti running text, audio dan braile. Kelima, hambatan sumber daya. Identifikasi ini terkait dengan sumber daya narapidana dan warga binaan penyandang disabilitas, dan juga sumber daya petugas layanan. Sumber daya mencakup pengetahuan dan informasi, juga ketersediaan kemampuan anggaran untuk pemenuhan hak-hak penyandang disabilitas di lembaga pemasyarakatan. ${ }^{13}$

Harry Kurniawan dalam buku "Perancangan Aksesibilitas Untuk Fasilitas Publik" mengatakan bahwa dalam implementasi setidaknya terdapat tiga cara atau analogi yang dapat digunakan untuk mengetahui aksesibilitas, yaitu : ${ }^{14}$

\section{Analogi Pintu Otomatis}

Pintu otomatis merupakan analogi yang paling baik dalam melihat implementasi aksesibilitas terkait fasilitas publik. dalam penggunaannya sehari-hari, pintu otomatis akan memberikan kemudahan dan kesempatan bagi siapa pun untuk melaluinya tanpa perlu melakukan adaptasi yang sulit atau pun berpengetahuan banyak. Analogi ini menggambarkan tentang keberadaan aksesibilitas yang bisa menjadi ssatu dengan elemen bangun lainnya dan tidak terlihat pengkhususan atau elemen tambahan dalam sebuhan lingkungan.

\section{Analogi Telpon Genggam}

Keberadaan telpon genggam merupakan pilihan. Sebagai sebuah alat komunikasi, telpon genggam memberikan kesempatan pengguna untuk memilih metode komunikasi yang paling sesuai atau paling nyaman untuk dirinya. Fasilitas telpon suara, pesan pendek atau video call dan lainnya sangat memungkinan pengguna untuk memilihnya. Sebagai ilustrasi, bagi penyandang disabilitas yang memiliki hambatan penglihatan, maka ia tentu akan memilih voice call dalam berkomnikasi. Bagi penyandang disabilitas yang memiliki hambatan pendengaran dan bicara (rungu wicara), fasilitas pesan pendek atau video call akan memudahkan untuknya. Analogi telpon genggam dalam implementasinya akan memberikan gambaran keberadaan elemen aksesibilitas sebagai pilihan bagi pengguna fasilitas tersebut. elemen aksesibilitas yang ada dalam lokasi tersebut akan melengkapi keberadaan elemen lain yang setara. Contohnya adalah keberadaan lift atau ramp, yang menjadi alternatif bagi keberadaan tangga.

\section{Analogi Pintu Darurat Pesawat Terbang}

Keberadaan pintu darurat dalam pesawat terbang adalah keharusan. Secara fungsi, pintu darurat adalah satu-satunya elemen dalam pesawat yang diharapkan untuk tidak dipergunakan, tetapi ketidakhadiran pintu darurat akan menyebabkan unsur kelayakan, keamanan, kenyamanan penumpang dan awak pesawat menjadi tidak terpenuhi. Begitu pula dengan keberadaan aksesibilitas, meskipun perumpaan ini terburuk dalam pola pikir implementasi aksesibilitas. Bisa jadi aksesibilitas menjadi elemen yang sangat jarang digunakan karena pengguna kursi roda dan difabel penglihatan sedikit. Tetapi keberadaannya harus ada, karena ia bisa menjadi unsur yang menyamankan, mengamankan, dan memberi nilai kelayakan sebuah fasilitas publik.

${ }^{13}$ Hari Kurniawan, dkk, Aksesibilitas Peradilan Bagi Penyangan Disabilitas, Pusham UII, 2015, hlm $61-65$

${ }^{14}$ Ibid, hlm 279-280 
Dalam praktek, aksesibilitas bagi penyandang disabilitas dengan demikian sangat berkaitan dengan desain sarana prasarana publik. Saat ini berkembang gagasan universal desain sebagai bagian penting untuk mewujudkan lingkungan yang aksesibel. Universal desain adalah sebuah pendekatan desain untuk menghasilkan fasilitas dan produk bagi semua orang secara umum, tanpa batasan fisik, rentang usia, dan jenis kelamin. Pendekatan universal desain mendorong semua pengguna dapat diakomodasi kebutuhannya dalam beraktivitas, bermobilitas, bergerak dan tidak mengeksklusifikan sebagian orang.

Terkait aksesibilitas dan universal desain, Undang-Undang No. 8 Tahun 2016, secara eksplisit telah menyebutkan bahwa penyandang disabilitas berhak memperoleh penyediaan aksesibilitas dalam layanan peradilan (Pasal 9 huruf f); memproleh aksesibilitas sarana penyelenggaraan pemilihan umum, pemilihan gubernur, bupati/walikota, pemilihan kepala desa atau nama lain (pasal 13 huruf g); dan secara spesifik dalam Undang-Undang ini ditegaskan secara sendiri terkait hak aksesibilitas, dimana penyandang disabilitas berhak atas aksesibilitas, meliputi : (a) mendapatkan aksesibilitas untuk memanfaatkan fasilitas publik; (b) mendapatkan akomodasi yang layak sebagai bentuk aksesibilitas individu (Pasal 18). Undang-Undang ini secara tegas memandatkan kepada pemerintah pusat dan daerah untuk menjamin aksesibilitas, diantaranya terkait layanan kebudayaan dan pariwisata (Pasal 85 ayat 1), rehabilitasi sosial (Pasal 92), setiap bangunan gedung (Pasal 98), menjadikan aksesibilitas sebagai salah satu syarat idzin mendirikan bangunan atau penerbitan dan perpanjangan sertifikat laik fungsi bangunan gedung (Pasal 99 ayat 1 dan 3), pemerintah wajib melakukan audit fasilitas aksesibilitas bagi penyandang disabilitas (Pasal 99 ayat 5), pertamanan dan pemakaman harus aksesibel (Pasal 103), pemerintah pusat dan daerah wajib mengawasi dan memastikan seluruh pemukiman yang dibangun pengembang memiliki aksesibilitas bagi penyandang disabilitas (Pasal 104 ayat 2) dan penanganan bencana harus memperhatikan aksesibilitas (Pasal 109 ayat 2). Bahkan Undang-undang ini menegaskan bahwa setiap orang dilarang menghalang-halangi dan/atau melarang penyandang disabilitas mendapatkan hak atas aksesibilitas (Pasal 143 huruf i).

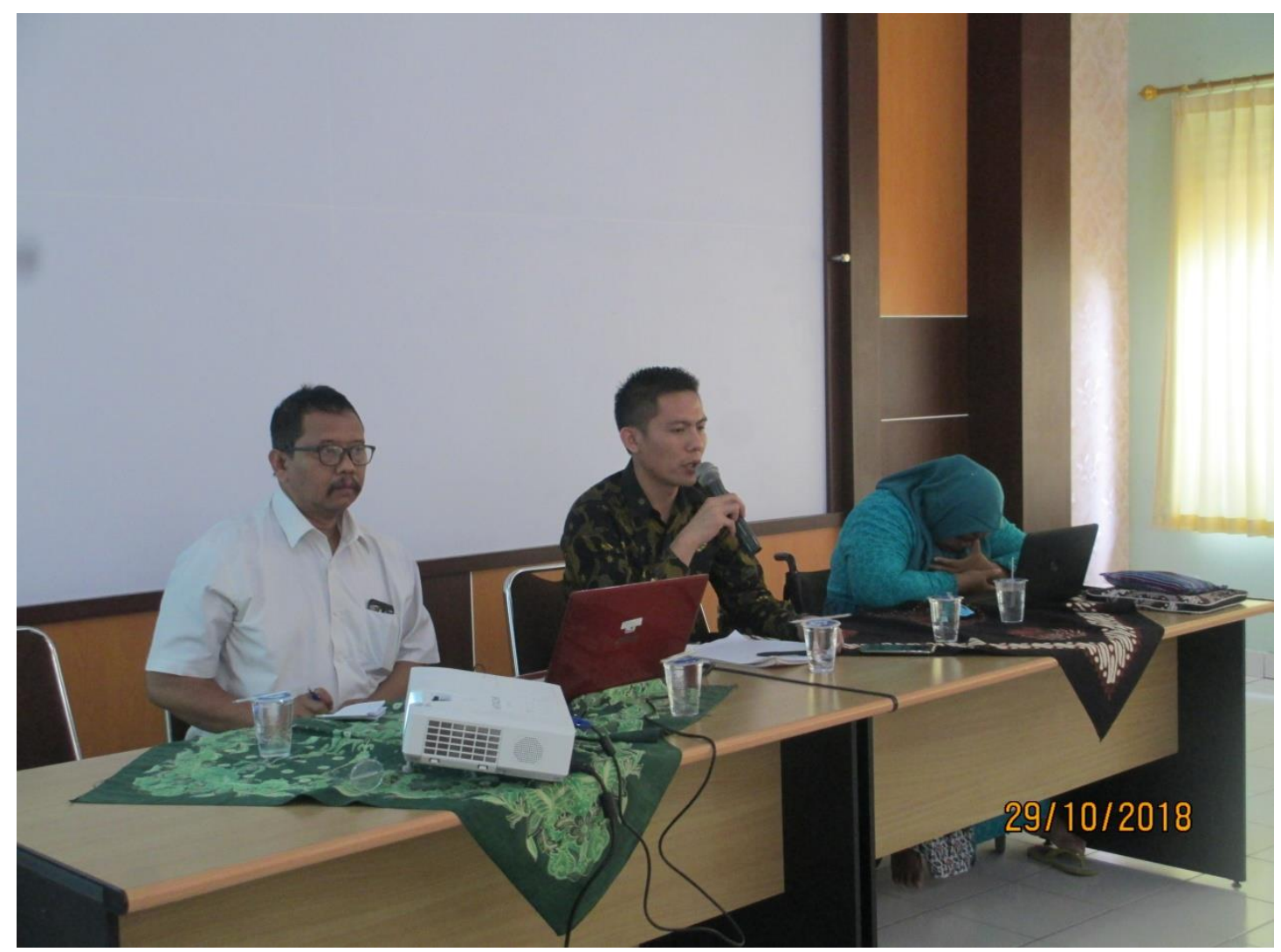




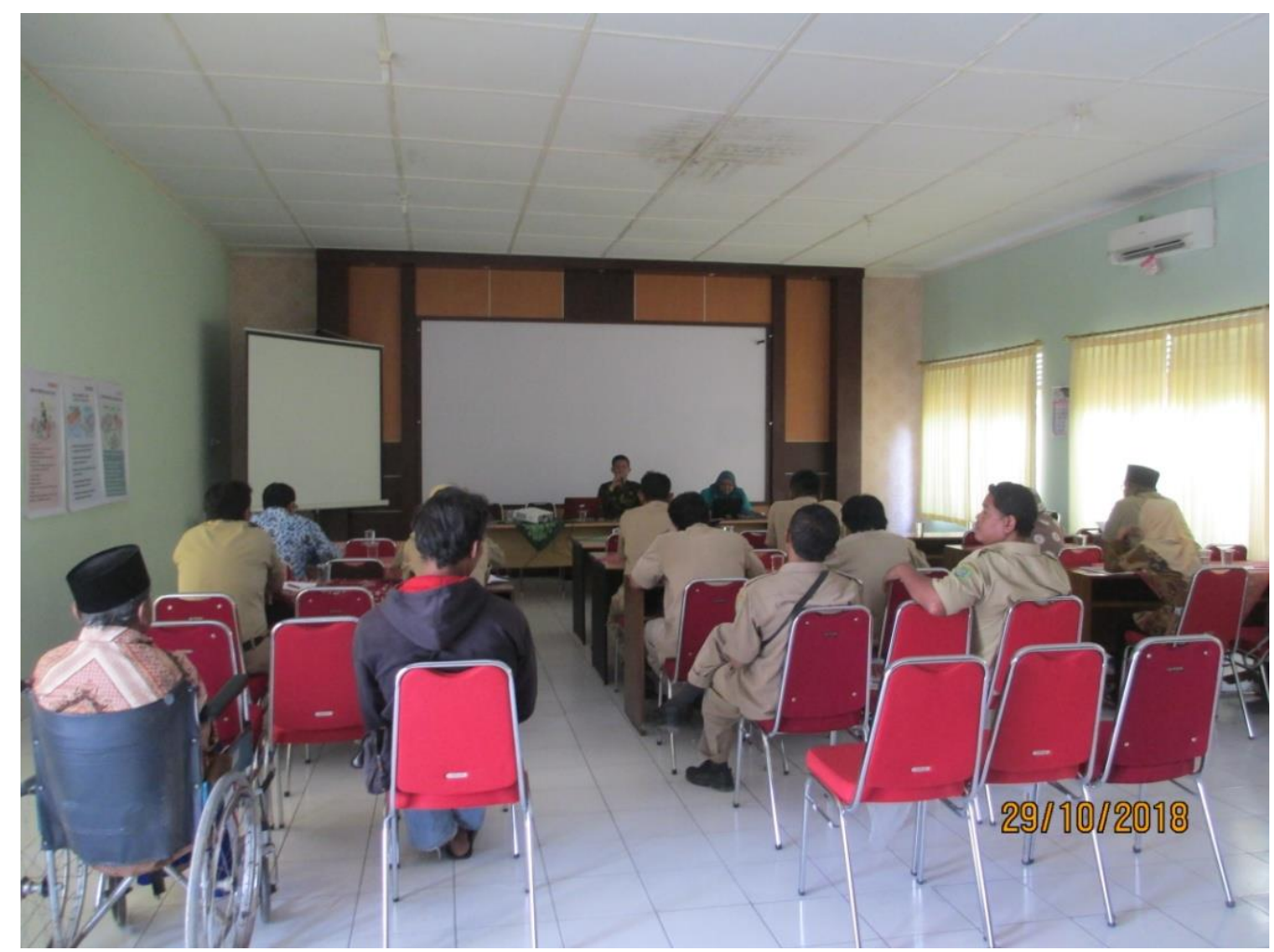

\section{KESIMPULAN DAN REKOMENDASI}

\section{Kesimpulan}

Kesimpulan yang dapat diambil dari kegiatan pengabdian ini adalah:

1. Pelayanan publik kepada para penyandang disabilitas tidak dapat diperlakukan sama dengan warga negara yang normal karena kondisi fisik mereka yang mengharuskan adanya perlakukan lebih. Sementara aparatur pemerintahan baik kecamatan maupun desa sendiri, masih banyak yang belum memahami bagaimana seharusnya pelayanan terhadap para penyandang disabilitas.

2. Para penyandang disabilitas masih banyak yang "mider" atau malu untuk berinteraksi dengan lingkungan sekitar. Hal ini disebabkan oleh masih banyak masyarakat yang merendahkan dan menganggap mereka sebagai orang cacat.

\section{Saran}

1. Kepada pihak pemerintah agar menyediakan sarana dan pra sarana yang memudahkan para penyandang disabilitas mendapatkan pelayanan publik serta membekali aparatur pemerintah agar memiliki pengetahuan tentang pelayanan terhadap penyandang disabilitas. Hal ini sesuai dengan amanat UU No 8 Tahun 2016 tentang Penyandang Disabilitas

2. Kepada masyarakat agar tidak mengecap penyandang disabilitas sebagai penyandang cacat dan merangkul mereka untuk dapat berinteraksi dengan normal dalam kehidupan sehari-hari.

3. Kepada DPPM UII untuk terus melakukan kerja-kerja pengabdian khususnya terhadap penyandang disabilitas di Indonesia agar mereka dapat menikmati haknya sebagai manusia dan sebagai warga negara Indonesia. 